\title{
NEGARA ADIL MAKMUR DALAM PERSPEKTIF FOUNDING FATHERS NEGARA INDONESIA DAN FILOSOF MUSLIM
}

\author{
Abu Tholib Khalik \\ Institut Agama Islam Negeri (IAIN) Raden Intan Lampung \\ e-mail: stai.tuba@yahoo.com
}

\begin{abstract}
This article elaborates on the concept of a fair and prosperous among the Indonesian founding fathers with the Muslim philosophers. Basic concepts of the founding fathers is Pancasila in which there is the word 'fair'. The word 'fair' is also a very serious discussion among Muslim philosophers. The Muslim philosophers underlined that fair is one of the basics of leadership exemplified by the Prophet Muhammad while leading the people of Madina multi-ethnic and multi-religious, and this of course is relevant to the context of Indonesia's multi-religious, multiethnic and multi-class. For founding fathers, desire to create a fair society and a prosperous lofty ideals and key for the Indonesian nation. Therefore, they feel how much suffering people of Indonesia as a nation occupied by foreign interchangeably. In the occupation of Indonesia was treated unfairly, and natural wealth confiscated. This goal was already thought by the Muslim philosophers. Therefore, in comparing the two is where the significance of the concept of a just and prosperous one.

Abstrak: Artikel ini akan mengelaborasi konsep negara adil dan makmur antara founding fathers (Para Pendiri Bangsa) Indonesia dengan para para filosof Muslim. Asas konsep founding fathers adalah Pancasila yang di dalamnya terdapat kata adil. Kata adil juga menjadi pembahasan yang sangat serius di kalangan filosof Muslim. Para filosof Muslim menggarisbawahi bahwa adil merupakan salah satu asas kepemimpinan yang diteladankan oleh Nabi Muhammad saat memimpin masyarakat Madinah yang multi-agama, dan ini tentu saja relevan dengan konteks Indonesia yang multiagama, multi-etnik, dan multi-golongan. Bagi founding fathers, keinginan mewujudkan masyarakat yang adil dan makmur merupakan cita-cita luhur dan utama bagi bangsa Indonesia. Sebab, mereka merasakan betapa menderitanya bangsa Indonesia ketika dijajah oleh bangsa asing yang silih berganti. Dalam penjajahan itu bangsa Indonesia diperlakukan tidak adil, dan kekayaan alam dirampas. Keinginan seperti ini ternyata sudah pula menjadi pemikiran para filosof Muslim. Karena itu, di sinilah signifikansi membandingkan kedua konsep adil dan makmur tersebut.
\end{abstract}

Keywords: Pancasila; fair; prosperous; founding fathers; Muslim philosophers

\section{A. Pendahuluan}

Populernya istilah "masyarakat adil makmur" di Indonesia bermula dari cita-cita luhur para founding father negara Indonesia antara lain Soekarno dan Mohammad Hatta. Cita-cita ini dipicu oleh kondisi sosial sejak dekade pertama 
abad ke-20, sehingga getaran semangat juang pemuda "Bumi Poetera" ketika itu bagaikan air bah yang turun dari gunung. Pada saat pembahasan rancangan Undang-undang Dasar (UUD) Negara Kesatuan Republik Indonesia Tahun 1945 salah seorang dari tokoh pejuang kemerdekaan Muhammad Yamin menyatakan, negara hendaknya tidak dirasakan sebagai ikatan hukum yang dapat mempersempit kehidupan rakyat. Rakyat akan menyambut gembira, jika UUD itu dapat membawa perubahan besar bagi kehidupan sosial ekonomi rakyat. ${ }^{1}$ Demikian tipologi pemikiran para pejuang kemerdekaan Indonesia dalam rangka mempersiapkan kemerdekaan Republik Indonesia dengan niat yang tulus suci untuk menciptakan kesejahteraan bagi seluruh rakyat Indonesia.

Di lain pihak pada penulisan karya ini akan dilihat pula produk pemikiran para tokoh besar dari kalangan filosof Muslim Ibnu Abi Rabi', al-Farabi, alMawardi, Ibnu Taimiyah sampai Ibnu Khaldun, yang dikenal di Timur dan Barat memiliki jangkauan ilmu yang demikian luas karena selain kemampuan intelektual mereka bahkan juga sebagian dari mereka adalah negarawan. Kajian ini juga akan menggunakan rujukan beberapa bahagian dari filsafat politik. Secara spesifik kajian ini akan diarahkan kepada masalah "masyarakat adil makmur" yang dalam tinjauan historisnya istilah itu telah dikenalkan sejak zaman Aristoteles, dikemudian hari dikembangkan oleh filosof Romawi Marcus Tullius Cicero (106-43 SM) dengan istilah khasnya societies civilies. Menurut salah seorang cendekiawan Indonesia bahwa, istilah-istilah para filosof besar tersebut bermakna, konsep kenegaraan ini sebagai gambaran dari negara kota dan bentuk koorporasi lainnya sebagai suatu kesatuan yang terorganisir. ${ }^{2}$ Dalam hal ini founding fathers negara Indonesia dalam rangka mempersiapkan pendirian Negara Kesatuan Republik Indonesia dahulu telah mengorganisir diri dalam suatu badan yang dikenal dengan BPUPKI untuk menentukan bentuk, asas dan hakikat dari Negara Kesatuan Republik Indonesia yang dicita-citakan itu.

Dalam sidang BPUPKI tanggal 1 Juni 1945 saat merancang asas Negara Kesatuan Republik Indonesia Pancasila salah seorang dari perumus Pancasila adalah Bung Karno. Dia mengatakan sebagaimana catatan berikut ini:

\footnotetext{
${ }^{1}$ Joko Siswanto, Filsafat Politik Pancasila, Refleksi atas Teks Perumusan Pancasila (Yogyakarta: Kepel Press, 2007), h. 139.

${ }^{2}$ Adeng Muchtar Ghazali, Civic Education; Pendidikan Kewarga-negaraan Perspektif Islam (Bandung: Benang Merah Press, 2004),h. 107.
} 
Prinsip Indonesia Merdeka dengan bertaqwa kepada Tuhan Yang Maha Esa. Prinsip Ketuhanan, Bukan saja bangsa Indonesia ber-Tuhan, tetapi masing-masing orang Indonesia hendaknya ber-Tuhan, Tuhannya sendiri. Yang Kristen menyembah Tuhan menurut petunjuk Isa al-Masih, yang belum ber-Tuhan menurut petunjuk Nabi Muhammad saw, orang Budha menjalankan ibadatnya menurut kitab-kitab yang ada padanya. Tetapi marilah kita semuanya ber-Tuhan. Hendaknya negara Indonesia ialah negara yang tiap-tiap orangnya dapat menyembah Tuhannya dengan cara yang leluasa. Segenap rakyat hendaknya bertuhan ...., dengan tiada egoisme agama, dan hendaknya Negara Indonesia satu Negara yang berTuhan. $^{3}$

Dalam hubungannya dengan masalah perekonomian maupun dalam sisi lain kehidupan warga negara kesatuan Republik Indonesia maksud Bung Karno di sini hendaknya tidak dilepaskan dari norma-norma agama maupun sosial yang ada pada masyarakat Indonsia sendiri. Pada dasarnya masyarakat Indonesia yang mayoritasnya menganut agama Islam, tentunya agama Islam diyakini merupakan sebagai alat pemersatu, dan hal ini secara terbuka difirmankan Allah dalam QS. Ali Imran (3): 103 yang artinya:

"Dan berpeganglah kamu semuanya kepada tali (agama) Allah, dan janganlah kamu bercerai berai, dan ingatlah akan nikmat Allah kepadamu ketika kamu dahulu (masa Jahiliyah) bermusuh-musuhan, Maka Allah mempersatukan hatimu, lalu menjadilah kamu karena nikmat Allah, orang-orang yang bersaudara; dan kamu telah berada di tepi jurang neraka, lalu Allah menyelamatkan kamu dari padanya. Demikianlah Allah menerangkan ayat-ayat-Nya kepadamu, agar kamu mendapat petunjuk."

Dalam hal ini Bung Karno mengingatkan dari sisi sejarah pada masa berkuasanya para khalifah Utsmaniyah di Turki terdapat dualisme hukum yakni pertama, Hukum atau Syari'at yang berlandaskan al-Qur'an dan al-Hadis, dan kedua hukum yang difirmankan oleh sultan/khalifah dan parlemen. Dualisme ini membawa kemunduran disebabkan pengaruh para syaikhul Islam yang masih berpandangan kolot, karena itu persatuan agama dan negara saat itu tidak membawa kemajuan di bidang ekonomi, bahkan menghambat, hal inilah yang melatar belakangi munculnya anjuran Bung Karno yang dikenalkan dalam istilah khasnya Rethingking of Islam. Berkenaan dengan analisis sejarah di atas maka lebih lanjut Bung Karno berpendapat baik kita terima pemisahan agama

${ }^{3}$ A.M.W. Pranarka, Sejarah Pemikiran tentang Pancasila (Jakarta: CSIS, 1985), h. 32. 
dari negara, tetapi kita akan kobarkan semangat seluruh rakyat dengan apinya Islam, sehingga semua utusan di dalam badan perwakilan adalah utusan Islam, dan semua putusan-putusan badan perwakilan itu bersemangat dan berjiwa Islam. Jika betul tuan-tuan punya rakyat begitu barulah bisa berkata bahwa Islamnya adalah Islam hidup, Islam yang dinamis. ${ }^{4}$ Suatu pandangan yang mirip dengan Muhammad Iqbal dari Pakistan yang menghendaki adanya pembaharuan cara pendekatan terhadap nash-nash Islam.

Mengenai keberadaan keyakinan para penganut agama lain menurut alQur'an memang tidak boleh diganggu gugat, mereka tetap diberikan kemerdekaan untuk menjalankan syari'at (hukum) agamanya, sepanjang mereka tidak berbuat sesuatu yang sifatnya memusuhi ataupun merugikan kaum Muslimin dalam segi materi, politik dan sebagainya. Menurut Penulis pandangan Bung Karno di sini relevan dengan pasal 31 Piagam Madinah yang dibuat oleh Rasulullah berbunyi:

Bagi kaum Yahudi Bani Tsa'labah berlaku ketentu sebagaimana yang berlaku bagi kaum Yahudi Bani 'Auf. Barang siapa yang melakukan aniaya atau dosa dalam hubungan ini maka akibatnya akan ditanggung oleh diri dan warganya sendiri. ${ }^{5}$

Scara sepintas ayat 31 Piagam Madinah ini mengesankan pentingnya persatuan intern warga negara, karena persatuan adalah salah satu pangkal dari adanya stabilitas yang juga merupakan jalan menuju kesejahteraan umum. Pandangan simpatik yang relevan dengan hal ini adalah dari cendekiawan Muslim Indonesia Jimly Asshiddiqie yang menyatakan bahwa, disamping pentingnya faktor kepemimpinan itu dibutuhkan pula agenda sosialisasi dengan beragam jenis media tradisional, konvensional maupun media yang didukung oleh teknologi informasi mutakhir, berkenaan dengan upaya reformasi ketatanegaraan kita dalam arti yang luas. ${ }^{6}$ Dapat diduga dari pendapat cendekiawan Muslim ini ialah kesadaran hukum masyarakat dari suatu negara, namun kesadaran itu tidaklah datang dengan sendirinya namun harus ada upaya-upaya yang serius dari kalangan aparatur negara.

${ }^{4}$ Badri Yatim, Soekarno Islam dan Nasionalisme (Jakarta: Logos, 1999), h. 140.

${ }^{5}$ Munawwir Syadzali, Islam dan Demokrasi (Jakarta: UI. Press, 1996), h. 13.

6Jmly Asshidiqie, Format Kelembagaan Negara dan Pergeseran Kekuasaan dalam UUD. 1945 (Yogyakarta: UII Pres, 2005),h. 31. 
Salah seorang ulama abad ke-13 M, Ibnu Taimiyah yang oleh beberapa penulis seperti Majid Fakhry dalam A History of Islamic Philosophy, termasuk Munawir Syadzali telah menggolongkan Ibnu Taimiyah sebagai salah seorang dari filosof Muslim yang pernah menyatakan bahwa, sesungguhnya mengatur urusan manusia merupakan kewajiban agama yang paling besar/bahkan agama tidak akan tegak tanpa hal itu. Demikian juga jihad, keadilan dan pelaksanaan hukuman-hukuman tidak dapat terlaksana tanpa kekuatan atau pemerintahan. Jadi, menyelenggarakan negara itu juga merupakan hal penting dalam pelaksanaan hukum syari'at. ${ }^{7}$ Betapa besar arti negara bagi upaya menegakkan keadilan, namun dilain kesempatan ada produk pemikirannya yang anomali, dengan menyatakan, Imam yang harus dita'ati itu adalah seorang yang sedang berkuasa, terlepas dari apakah ia adil atau zalim. ${ }^{8}$ Sekitar masalah ini Ibnu Taimiyah berpegang pada QS. al-Nisā' (4); 59:

"Hai orang-orang yang beriman, taatilah Allah dan taatilah Rasul-Nya, dan Ulil Amri di antara kamu."

Kebalikan dari itu realitas yang tampak pada masyarakat Indonesia saat pecah aksi reformasi sekitar tahun 1988 yang lalu dalam rangka menentang pemimpin yang dianggap zalim sehingga muncullah perilaku para pendemo yang melakukan pengrusakan terhadap tempat-tempat usaha, fasilitas-fasilitas umum dalam menyampaikan aspirasinya, kondisi semacam ini masih sangat jauh dari apa yang disebutkan di atas oleh Soedjadi sebagai "wisdom" itu, demikian pula Mallarangeng menyatakan bahwa, warga negara yang baik adalah warga negara yang sadar politik, karena kesadaran politik merupakan prasyarat dalam mewujudkan masyarakat yang adil, demokratis, wajar dan manusiawi. ${ }^{9} \mathrm{Hal}$ ini menunjukkan kebenaran pendapat dari Asshiddiqie di atas, namun bisa juga sikap yang demikian sebagai keterlambatan ataupun kelemahan dalam pendidikan politikyang sehat dari pemerintah terhadap masyarakat.

Jika pandangan ini dihubungkan dengan kondisi Indonesia dalam kehidupan berbangsa dan bernegara memang sudah sepatutnya diperhatikan, apa yang dikatakan Khaldun sikap nomaden (suku Arab pengembara)

89.

${ }^{7}$ Abdul Karim Zaidan, Masalah Kenegaraan dalam Islam, terj. Abd.Azis (Jakarta: Al-Amin, 1984), h.

${ }^{8}$ Ahmad Syafii Maarif, Islam dan Masalah Kenegaraan (Jakarta: LP3ES, 1985), h. 33.

${ }^{9}$ Andi Mallarangeng, dkk., Otonomi Daerah, Demokrasi dan Civil Society (Jakarta: Media Grafika, 2000), h. 31. 
berkenaan dengan hubungan antara rakyat dan pemerintah.10 Nomaden memang tidak menganggap penting sistem kemasyarakatan sehingga mereka sulit diatur, tidak mau tunduk pada pemerintah, bahkan para pemimpin mereka amat tergantung kepada sifat solidaritas mereka.

Sungguh pun harus diakui bahwa, ada perbedaan asasi antara kaum Nomaden yang disebut Khaldun dan masyarakat Indonesia saat ini, karena kaum Nomaden yang hidup di padang pasir itu mendapat rahmat Allah, dengan hadirnya Imam dunia Nabi Muhammad, dengan hadisnya di samping kitab suci al-Qur'an. Sedangkan dilain pihak masyarakat Indonesia selain multi etnik, multi budaya juga multi agama, sehingga Bung Karno pernah menyatakan dalam satu pidatonya tertanggal 22 April 1959 bahwa, dalam rangka mengakhiri penderitaan rakyat, revolusi harus berlandaskan kepada Trilogi Amanat Penderitaan Rakyat (Ampera) diantaranya bertujuan menciptakan masyarakat yang adil dan makmur.11

Pandangan ini relevan dengan Kant tentang hak dan keadilan itu harus ada di dunia. Jika manusia secara alamiah baik, maka kondisi keadilan publik dan hak mereka merupakan kondisi alami, jika mereka jahat lantas, tidak ada keamanan hak di kalangan mereka, maka itu adalah kesalahan mereka. Nampaknya di sini Kant bermaksud mengatakan bahwa ketertiban umum itu tidak semata-mata tergantung kepada kekuatan dan kekuasaan pemerintah saja namun juga kearifan (wisdom) masyarakatnya sangat dibutuhkan bahkan lebih dari itu, turut pula menentukan. Nampaknya yang sejalan dengan gagasan Trilogi Ampera Bung Karno adalah pandangan seorang filosof besar abad XVIIXVIII John Locke, civil society itu adalah suatu masyarakat yang memiliki kebebasan hak milik, negara harus melindungi dan menghormati kebebasan serta hak milik mereka. ${ }^{12}$ Tetapi untuk kondisi sosial Indonesia haruslah dihindari hal-hal yang berbau Kapitalism, karena kebebasan itu harus disinkronkan dengan ayat (3) pasal 33 UUD 1945 bumi dan air dan kekayaan alam yang terkandung di dalamnya dikuasai oleh negara dan dipergunakan untuk sebesar-besarnya kemakmuran rakyat.

\footnotetext{
${ }^{10}$ Charles Issawi, Filsafat Islam tentang Sedjarah: Pilihan dari Muqaddimah Karangan Ibn Chaldun dari Tunis, disalin oleh A. Mukti Ali" (Jakarta: Tintamas, 1962), h. 79-80.

11Wawan Tunggul Alam (ed.), Bung Karno Menggali Pancasila, Kumpulan Pidato Oakarta: Gramedia Pustaka Utama, 2001), h. 79.

${ }^{12}$ Adeng Muchtar Ghazali, Cïvic Education, h. 108.
} 
Beberapa kutipan dari para cendekiawan Indonesia, Khaldun dan para filosof di atas memberi kesan betapa pentingnya melakukan kajian kritis terhadap Filsafat Politik dari para filosof Muslim dalam hubungannya dengan tujuan utama proklamasi kemerdekaan Indonesia yakni sebagaimana dicitacitakan bangsa Indonesia yakni masyarakat adil dan makmur. Kendati ada perbedaan-perbedaan yang prinsip antara masyarakat Indonesia dan kaum Nomaden maupun masyarakat Arab sebelum dan semasa hidupnya Ibnu Khaldun, namun setidaknya ruh dari falsafah hidup bangsa Indonesia Pancasila yang merupakan landasan dasar dari pandangan founding fathers negara Indonesia dalam hal masyarakat adil makmur cukup memadai untuk mendekati pandangan para filosof Muslim di sekitar masalah masyarakat adil makmur.

\section{B. Masyarakat Adil Makmur}

Pada bagian pendahuluan di atas sepintas telah disinggung tentang cita-cita masyarakat adil makmur dari para founding father negara Indonesia yang dilatarbelakangi oleh perlakuan tidak adil dari penjajah yang dirasakan sangat tidak adil. Selanjutnya di sini akan dideskripsikan pandangan para filosof Muslim klasik, kemudian konsepsi founding fathers.

\section{Filosof Muslim Klasik}

Filosof Muslim yang akan dijadikan bahan kajian di sini adalah dimulai Ibnu Abi Rabi', seterusnya adalah Al farabi, Ibnu Taimiyah terakhir Ibnu Khaldun, dengan idak menafikan pendapat dari para filosof maupun pakar filsafat kontemporer.

\section{a. Ibn Abi Rabi'}

Tokoh dalam karyanya yang berkaitan dengan masalah kenegaraan tidak dapat dilepaskan dari pengaruh filsaat Yunani terutama Plato, kemudian sebagai Muslim pandanganya selalu saja diwarnai dengan tidak menafikan adanya dalildalil naqli. Pertama manusia itu sebagai makhluk sosial mempunyai sifat selalu ingin berkumpul, kemudian kedua Tuhan telah meletakkan peraturanperaturan dakam kehidupan bersama itu tentang hak dan kewajibanya sebagai rujukan yang wajib dipatuhi oleh semua pihak dan yang ketiga Tuhan juga telah mengangkat penguasa-penguasa yang harus bertugas untuk menjaga berlakunya peraturan-peraturan rakyat dari Tuhan dan mengendalikan masyarakat 
berdasarkan hukum Tuhan.13 Tentang hukum Tuhan dalam hal ini adalah firman Allah baik yang termaktub dalam al-Qur'an maupun yang berupa hadis Qudsi bahkan sabda Rasulullah. Dalam QS. al-Mā’idah (5): 8 Allah berfirman:

"Hai orang-orang yang beriman hendaklah kamu Jadi orang-orang yang selalu menegakkan (kebenaran) karena Allah, menjadi saksi dengan adil. dan janganlah sekali-kali kebencianmu terhadap sesuatu kaum, mendorong kamu untuk berlaku tidak adil. Berlaku adillah, karena adil itu lebih dekat kepada takwa. dan bertakwalah kepada Allah. Sesungguhnya Allah Maha Mengetahui apa yang kamu kerjakan."

Demikian jelasnya bahwa ayat ini jika dihubungkan dengan pandangan Ibnu Abi Rabi' berkenaan dengan kewajiban pemerintah dalam mengendalikan masyarakatnya yakni berlaku adil dan mampu menegakkan keadilan, hal ini yang kemudian juga dapat ditemui dalam pandangan Ibn Abi Rabi' selanjutnya tentang tabiat manusia menyatakan, manusia itu bukanlah malaikat yang kebal godaan dan tak akan pernah melakukan kejahatan, bahkan manusia itu selalu saja ditarik kearah kejahatan. Oleh sebab itu Ibn Abi Rabi' lebih menekankan seyogyanya pemimpin itu haruslah orang yang termulia di negara itu, sebab orang yang harus mencegah orang lain dari kejahatan itu adalah orang yang mampu memberikan contoh terlebih dahulu. Jika pemimpin sudah tidak mampu menjadi teladan kebaikan, kebenaran dan keadilan maka mustahil akan diteladani oleh oleh masyarakatnya.

Sungguhpun sebenarnya hal ini kurang seirama dengan pandangan Ibnu Taimiyah, yaitu berkenaan dengan hubungan antara rakyat dan Kapala Nagara, dimana beliau menghendaki agar Imam/Kepala Negara itu harus dita'ati tanpa reserve. Dalam hal ketaatan ini sungguh nampak suatu kejanggalan, sebagaimana dikemukakan olah seorang cendekiawan Muslim Indonesia bahwa, Imam yang harus dita'ati itu adalah seorang yang sedang berkuasa, terlepas dari apakah ia adil atau zalim. ${ }^{14}$ Secara sepintas point ini justru kontradiksi dengan pendapat Ibnu Abi Rabi' yang menghendaki agar seorang Raja/Kepala Negara/Imam itu wajib sebagai orang yang layak dijadikanteladan karena mampu barlaku adil, tetapi mungkinkah kezaliman yang dimaksudkan Taimiyah di sini ada kriterianya sendiri, maka timbullah pertanyaan, Raja/Kepala

13Munawwir Syadzali, Islam dan Demokrasi, h. 45.

${ }^{14}$ Ahmad Syafii Maarif, Islam dan Masalah Kenegaraan, h. 33. 
Negara/Imam yang bagaimana yang diidamkan oleh Ibnu Taimiyah dan sejauh mana keta'atan yang dimaksudkan itu? Insya Allah pada bahagian berikutnya akan dapat turut dibahas.

Hanya saja dalam hal ini perlu juga dijadikan pedomma sekilas pandangan dari Ibnu Rusyd yang mengatakan bahwa, dalam kasus-kasus tertentu akal manusia memang tidak dapat mencapai bentuk pengetahuan yang sungguhsungguh diperlukan dalam mencapai bentuk kesempurnaan dalam rangka menuju kepada kebahagiaan manusia. ${ }^{15}$. Karena ada faktor-faktor yang harus diperhatikan di antaranya adalah manusia memang berhak atas kebenaran, namun bukanlah yang Maha Benar, demikian pula dalam hubunganya dengan masalah kenegaraan dalam kondisi tertentu memang mengharuskan adanya sikap tertentu pula.

\section{b. Al-Farabi (870-950 M)}

Jalan pemikiran yang sangat dekat dengan konsepsi founding fathers negara Indonesia di sekitar masalah negara yang adil makmur terdapat dalam kitab alMadīnah al-Faḍilah al-Farabi yang menyatakan bahwa, keadilan itu sangat bersangkut paut dengan distribusi dan juga pemeliharaan harta benda yang berharga, semua ini dinyatakan secara tegas berupa keamanan, kesehatan, kedudukan dan milik material pada umumnya. Pada sumber lain dinyatakan bahwa al-Farabi dalam kehidupan bernegara/politik mengutamakan masalah moralitas atau budi pekerti. Dari itu al-Farabi membagi masyarakat itu kedalam dua bahagian yakni masyarakat sempurna dan masyarakat yang tidak sempurna. ${ }^{16}$ Tidak dapat dipungkiri kalau masala distribusi di sini sangat terkait dengan masalah budi perkerti maupun pemeliharaan merupakan satu sistem yang tidak terpisahkan bahkan patut dikatakan ada persenyawaan. Karena pada distribusi ada peluang untuk terjadi ketidak adilan jika para pelakunya tidak berbudi, pemeliharaanpun demikian jika sang pemeliharaan hak-hak demokrasi rakyat misalnya tidak mampu bersikap tegar dan tegas pada kebenaran niscahya rakyat akan dirugikan.

Dalam hal ini dikatakan Ibn Sīnā secara tegas bahwa, adanya kepala rumah tangga atau lebih popular kepala keluarga, kemudian barulah datang adanya

15Majid Fakhry, Sejarah Filsafat Islam, terj. Mulyadi (Jakarta: Temprin, 1987), h. 390.

16Munawair Syadzali, Islam dan Demokrasi (Jakarta: UI Press, 1993), h. 51. 
kepala negara, yang tidak lain di dalam sifatnya sama dengan "bapak rakyat" yang memimpin keluarga besar yang bernama negara. ${ }^{17}$ Pandangan ini menggambarkan bahwa negara dalam pandangan Ibn Sinā sebagai satu keluarga besar, berarti ikatan batin antara segenap warga negara dengan pemerintah itu bukanlah semata-mata karena konstitusi atau undang-undang negaranya, namun lebih disebabkan karena landasan taqwa kepada Allah yang demikian teguhnya sehingga terwujud dalam rasa persaudaraan yang tiada lain hanya berlandaskan iman Islam (ukhuwwah Islämiyyah).

Satu hal yang unik dari al-Farabi ialah tentang autokrasi, namun dalam ini ada suatu yang khas yakni, di dalam negara itu yang terpenting adalah Kepala Negara yang ibarat hati dalam tubuh manusia. Karena hati adalah unsur badan manusia yang paling sempurna, maka kepala negara haruslah dipilih orang yang paling sempurna dari segenap warganegara. ${ }^{18}$ Pokok pandangan ini mengesankan istilah Plato yang mengatakan Filosof menjadi raja atau raja menjadi filosof. Hati secara biologis memang merupakan alat penyaring darah, dalam hubungannya dengan masalah kenegaraan kepala negara berkewajiban menyaring warga negaranya yang akan dijadikan aparatur negara dari kalangan orang-orang yang bersih dalam arti akhlaknya. Bilamana darah yang tidak bersih itu sampai mengalir kedalam tubuh maka darah itu akan menjadi bibit penyakit yang akhirnya akan mematikan tubuh (dalam artian ini adalah negara yang bersangkutan).

\section{c. Ibn Taimiyah (1263-1329 M)}

Pandangan seorang pemikir besar Muslim Taqiuddin Ahmad Ibnu Taimiyah dalam masalah kenegaraan menurut banyak penulis, sebagian besarnya merupakan tafsirannya dari ayat-ayat al-Qur'an dan Sunnah Rasulullah, kemudian selain itu beliau juga memperoleh masukan dari empiriknya yang dikaji dengan sistem deduktif, dengan demikian layak kalau disebut bahwa produk pemikiran Ibn Taimiyah itu terutama dalam masalah kenegaraan berlandaskan dalil-dalil naqli dan juga dalil aqli.

Pokok-pokok pemikirannya, yang berkaitan dengan masalah kenegaraan menunjuk-kan bahwa, Agama yang benar itu haruslah mempunyai Kitab yang

17Zainal Abidin Ahmad, Konsep Politik dan Ideologi Islam (Jakarta: Bulan Bintang, 1984), h. 21.

18Poerwantana, dkk, Seluk-beluk Filsafat Islam (Bandung: Rosda Bandung, 1988), h. 139. 
dapat menjadi sumber dari segala sumbar hukum (maksudnya al-Qur'an) dan pedang sebagai penolong. Dalam hal ini yang dimaksudkan dengan istilah pedang tidak lain adalah Negara yang harus berfungsi sebagai alat bagi penegakan dan pelaksanaan hukum yang dikehendaki Allah sebagaimana termaktub dalam al-Qur'an dan juga Hadis, baik dalam Hadis Qudsi ataupun yang lainnya.

Al-Qur'an sebagai pedoman hidup bagi Muslim baik dalam hal hukum Negara ataupun dalam beberbagai segi penghidupan lainnya. Negara sebagai alat bagi penegakan hukum dalam versi Ibn Taimiyah ini, diandaikan antara keduanya ibarat dua sisi dari satu mata uang, sehingga jika tidak ada sisi yang satu maka tidak akan ada sisi yang lainnya, oleh sebab itu patut dipahami bahwa adanya Negara itu menurut Ibnu Taimiyah adalah wajib, ibarat wajibnya wudhu' sebelum shalat. Lantas bagaimana mungkin dapat mendirikan negara tanpa warga negara, menurut Ibnu Khaldun, suatu suku mungkin dapat membentuk dan memelihara suatu negara apabila suku itu memiliki sejumlah karakteristik sosial-politik tertentu, yang disebut 'Ashabiah. ${ }^{19}$ Istilah 'Ashabiah di sini dapat diartikan dengan istilah Indonesia yakni nasionalisme, atau rasa kebangsaan yang membuahkan persatuan dan kesatuan.

Kemudian mengenai ketergantungan antara Islam sebagai agama dan negara sebagai alat penolongnya, satu sama lainnya saling memiliki ketergantungan sehingga dikatakan Ibn Taimiyah bahwa, Negara itu sebagai akibat dari adanya iman masyarakat Islam, sebaliknya negara sebagai suatu alat untuk menegakkan syari'at Islam demi terciptanya masyarakat beriman yang aman, damai berlandaskan iman kepada Allah. Dalam pandangan Ibnu Taimiyah dinyatakan, sesungguhnya, mengatur urusan manusia marupakan kewajiban agama yang paling besar, bahkan agama tidak akan tegak tanpa itu. Karana Allah telah mewajibkan untuk menyuruh berbuat baik, mencagah kemunkaran dan menolgng orang yang taraniaya. Bagitu juga jihad, keadilan dan pelaksanaan hukuman-hukuman yang kasemuanya diwajibkan Allah, tidak dapat terlaksana tanpa kekuatan atau pemerintahan. Jadi, menyelenggarakan negara merupakan hal penting dalam pelaksanaan hukum syari'at. ${ }^{20}$

19Zullifan, 2008, http://muhammad-zulifan.multiply.com. h. 4. Diakses 07-09-2010.

${ }^{20}$ Abdul Karim Zaidan, Masalah Kenegaraan, h. 2. 
Ibnu Taimiyah juga menganjurkan agar para penguasa supaya menggalakkan musyawarah yang berlandaskan ayat-ayat al-Qur'an, seperti termaktub dalam QS. al-Syūrā ayat 38:

“... dan (bagi) orang-orang yang menerima (mematuhi) seruan Tuhannya dan mendirikan salat, sedang urusan mereka (diputuskan) dengan musyawarah antara mereka, dan mereka menafkahkan sebagian dari rezeki yang Kami (Allah) berikan kepada mereka."

Hal ini dapat dimengerti bahwasanya negara yang dikehendaki oleh Ibn Taimiyah sejalan dengan maksud ayat tersebut di atas, dalam istilah kenegaraan modern ini adalah negara republik atau negara demokrasi. Sebab demokrasi pada hakikatnya dimaksudkan agar dengan musyawarah itu bisa diperoleh suatu keputusan yang disepakati bersama, demi kepentingan bersama, tidak hanya menguntungkan suatu pihak namun merugikan pihak yang lain. Di sini tidak berlaku sistem mayoritas versus minoritas, karena kepentingan bersama itu menjadi prioritas dalam mencapai mufakat, yang pada akhirnya akan terwujudlah keadilan yang merata, tanpa ada diskriminasi.

Bilamana keadilan dapat ditegakkan tentu tak akan terjadi konflik intern dalam suatu negara, sebagaimana kondisi masyarakat Madinah semasa dipimpin oleh Nabi Muhammad, sungguhpun pada masa itu masyarakat Madinah belumlah seluruhnya Muslim, tetapi tidak ada konflik karena keadilan memang betul-betul dapat ditegakkan secara merata. Sebaliknya jika terjadi ketidak adilan hingga suatu golongan atau kelompok diuntungkan dan kelompok lainnya justeru dirugikan, inilah salahsatu pangkal dari perpecahan yang pada akhirnya melahirkan instabilitas. Suatu kenyataan yang sulit dibantah kebenarannya adalah apabila terjadi peperangan akan menimbulkan dampak negatif bagi masyarakat, di antaranya adalah memburuk nya situasi politik, keamanan dan ekonomi. Seperti disarahkan bahwa, Ibnu Taimiyah yang baru berusia tujuh tahun ketika Harran diserang oleh pasukan Mongol, ia beserta kedua orang tuanya terpaksa harus mengungsi ke Damaskus. Peristiwa tragis ini sangat membekas di dalam hati Ahmad (Ibn Taimiyah) yang masih muda dan sensitif, dan tak dapat di lupakannya. ${ }^{21}$ Kalaupun ada serangan pihak luar terhadap suatu Negara sedangkan dalam Negara itu baik pemerintah maupun

${ }^{21}$ Qamarudin Khan, Pemikiran Politik Ibnu Taimiyah, terj. Anas Mahyuddin (Bandung: Salman ITB, 1983), h. 10. 
rakyatnya solid, maka sulit kemungkinan untuk menjadikan negara itu bubar atau terjajah oleh pihak yang menyerang.

Selain dari hasil kajian Ibnu Taimiyah terhadap dalil-dalil naqli, turut memberi inspirasi kepadanya juga apa yang dapat dilihat langsung oleh Ibnu Taimiyah seperti pengangkatan Khalifah fiksi di Kairo juga turut menyokong kedalaman dan ketajaman alam pemikirannya. Pemikiran Ibnu Taimiyah tentang politik yang akan dibahas lebih lanjut dalam karya tulis ini tidak dapat dilepaskan dari pengaruh ajaran Syi'ah yang sama sekali bertolak belakang dengan keyakinannya seperti masalah Imamah, yang oleh kaum Syi'ah itu dianggap sebagai rukun Iman, penolakan Ibnu Taimiyah tentang hal ini tertuang dalam karya tulisnya Minhaj.

Kalau ditinjau dari sudut sejarah pemerintahan di kalangan kaum Muslimin sejak masa kepemimpinan ummat di bawah Nabi Muhammad hingga pada masa kepemimpinan para Khulafaurrasyidin, ternyata apa yang telah berlaku di masa itu telah berhasil dengan baik bahkan amat memuaskan, maka apa sebab Ibnu Taimiyah yang reformis itu justru berpendirian lain? Suatu hal yang merupakan keunikan dalam gaya pemikiran Ibnu Taimiyah, yaitu berkenaan dengan hubungan antara rakyat dan Kapala Nagara, dimana beliau menghendaki agar Imam/Kepala Negara itu harus dita'ati tanpa reserve. Dalam hal ketaatan ini sungguh nampak suatu kejanggalan, sebagaimana dikemukakan olah seorang cendekiawan Muslim Indonesia bahwa, Imam yang harus ditaati itu adalah seorang yang sedang berkuasa, terlepas dari apakah ia adil atau zalim. ${ }^{22}$ Secara sepintas point ini justru kontradiksi dengan pendapatnya sendiri yang menghendaki agar seorang raja/kepala negara diwajibkan barlaku adil, tetapi mungkinkah kezaliman yang dimaksudkannya di sini ada kriterianya sendiri, maka timbullah pertanyaan, raja/kepala negara yang bagaimanakah yang diidamkan oleh Ibnu Taimiyah? Sejauh mana ketaatan yang dimaksudkan itu?

Islam sebagai suatu agama dan pemerintahan/negara sebagai wadah pemersatu kekuatan ummat dalam Syari'atnya satu sama lain saling tarkait dan tak mungkin untuk dapat dipisahkan, tentang ini Ibnu Taimiyah mengatakan bahwa, sesungguhnya, mengatur urusan manusia merupakan kewajiban agama yang paling besar/bahkan agama tidak akan tegak tanpa hal itu. Begitu juga

${ }^{22}$ Ahmad Syafii Maarif, Islam, h. 33. 
jihad, keadilan dan pelaksanaan hukuman tidak dapat terlaksana tanpa power atau pemerintahan. Jadi, menyelenggarakan negara itu juga merupakan hal penting dalam pelaksanaan hukum syari'at. ${ }^{23}$ Betapa besar arti negara bagi usaha menegakkan Syari'at Islam itu. Sebab Islam dalam arti syari'at (hukum) harus ditegakkan oleh suatu badan penegak hukum, itupun belum tentu efektif, karena tergantung kepada kualitas para penegak hukum itu sendiri.

\section{d. Ibn Khaldun (1332-1406 M)}

Menurut pandangan Ibn Khaldun, kekuasaan itu ada karena tentara, dan tentara itu ada karena harta yang bersumber dari rakyat seperti pajak, dan pajak itu merupakan sumber pembangunan, sedangkan pembangunan itu sendiri ada karena keadilan. Keadilan itu ada karena kejujuran aparatur negara, dan kejujuran aparatur negara itu karena adanya kejujuran para wazier (Menteri), yang berada dibawah pengawasan seorang Raja serta tergantung pula kepada kemampuan sang raja dalam bersikap dan bertindak ${ }^{24}$ Menurut suatu catatan, dari pandangan Khaldun sendiri dikatakannya, agama (=Islam) menetralisir perasaan iri dan persaingan tidak sehat antar sesama anggota kelompok, menimbulkan rasa solidaritas, serta tujuan dan pandangan yang sama. Bilamana mental keagamaan dan solidaritas kelompok telah melemah hingga akhirnya roboh karena serangan gencar dari kegemaran terhadap kehidupan bermewahmewahan dan kesenangan tanpa batas, sehingga orang-orang yang tadinya telah bersatu dalam semangat kerjasama, mungkin akan terpisah bahkan lebih buruk lagi menjadi gemar berbohong, menipu, mencuri, bersumpah palsu dan menjalankan riba. ${ }^{25}$ Sejalan dengan itu menarik rasanya satu statemen Whitehead dalam masalah demokrasi ekonomi, sebagaimana dikutip dalam buku Transisi Menuju Demokrasi bahwa, kemajuan ekonomi dan keadilan yang merata dapat dicapai dengan baik melalui kerjasama manusia yang bebas dalam suatu kerangka lembaga demokratik. ${ }^{26}$ Memang tidak dapat dipungkiri bahwa yang namanya demokrasi itu adalah sesuatu yang berpatokan pada suara terbanyak dan terutama kepentingan orang terbanyak, dalam hal apa pun.

${ }^{23}$ Abdul Karim Zaidan, Masalah Kenegaraan, h. 89.

${ }^{24}$ Ibn Khaldun, Muqaddimah, terj. Ahmadi Thoha (Jakarta: Pustaka Firdaus, 1986), h. 65.

${ }^{25} \mathrm{H}$. Robert Lauer, Perspektif tentang Perubahan Sosial, terj., Alimandan (Jakarta: Bina Aksara, 1989, h. $45-46$.

${ }^{26}$ Ade A. Widjanarno, Transisi Menuju Demokrasi, Tinjauan Berbagai Perspektif (Jakarta: LP3ES, 1983), h. 5. 
Dalam kitab Muqaddimah tertulis bahwa, sifat ketidakjujuran para penguasa dan tijar, seperti pemalsuan, pembayaran hutang terlambat, adalah merupakan penghambat dalam dunia usaha untuk itu patut dihindarkan. Untuk menghindarkan hal ini setiap melakukan transaksi haruslah secara tunai, jika harus juga terjadi hutang piutang haruslah dilakukan dengan perjanjian tertulis. Semuanya itu dimaksudkan, jika terjadi perselisihan antar pihak dalam perniagaan itu, maka pihak pengadilan dapat melakukan analisa hukum yang didukung oleh fakta-fakta dan bukti-bukti akurat. ${ }^{27}$ Begitu pula dalam kitab Muqaddimah, tentang hal-hal sebagaimana tersebut telah dinyatakan bahwa, untuk mewujudkan masyarakat yang teratur dan harmonis (ma'luf) itu harus lebih dahulu diciptakan suasana aman damai, keadilan yang merata, serta dilaksanakan oleh aparatur negara yang bersih dari tindakan $\mathrm{KKN}$, dengan demikian badan pemerintah itu akan berwibawa. ${ }^{28}$ Statemen ini cenderung mengarah kepada keamanan dan ketertiban masyarakat dalam istilah Polri "Kamtibmas". Namun tak selamanya maslah Kamtibmas harus dipercayakan kepada Polisi, maka lebih tegas Khaldun mengatakan ketika kesadaran beragama telah menurun dikalangan manusia, dan mereka menggunakan hukum-hukum yang tidak dijiwai syari'at (Islam), bahkan agama hanya dijadikan cabang dari ilmu-ilmu, serta agama hanya diperoleh melalui jalur pendidikan formal, maka keteguhan jiwa mereka juga akan berkurang. Tatkala keteguhan mental agama itu telah menurun tentunya akan terjadi ketidak stabilan, karena kebutuhan akan ekonomi senantiasa meliputi alam pikiran manusia, maka manusia akan menghalalkan segala cara guna mendapatkan harta. Pada saat semacam inilah al-kifāyah dari seorang pemimpin negara sangat diperlukan. Karena dia dituntut agar dapat menegakkan keadilan sosial secara merata di kalangan rakyatnya, demi menuju kepada keharmonisan hidup secara horizontal pada intern masyarakat dan keharmonisan vertikal antara masyarakat dengan pemerintahnya. ${ }^{29}$ Namun di balik itu semua Khaldun tidak terlalu berpihak kepada rakyat dan tidak pula semata-mata menyerahkan masalahnya kepada pihak pemerintah, hingga dalam satu komentarnya, pengaruh kondisi politik yang tidak stabil akan menimbulkan implikasi yang negative terhadap kehidupan ekonomi suatu negara. Tidak jarang pula terjadi dalam kondisi semacam itu, kata Khaldun, pribadi-pribadi yang gesit akan

27Ibn Khaldun, Muqaddimah, h. 468-469.

28 Ibid., h. 41.

${ }^{29}$ Ibid., h. 148-149. 
menarik. keuntungan dari situasi yang kisruh seiring dengan runtuhnya suatu dinasti pemerintahan ${ }^{30}$ Secara ringkas dalam hal ini yang diharapkan oleh Ibnu Khaldun adalah upaya pemerintah yang disertai dengan kesadaran hukum warga negara dengan landasan iman kepada Allah, jika ini tidak ada maka stabilitas dalam suatu negara akan sulit diwujudkan kemudian klimaksnya adalah instabilitas yang berakibat rusaknya perekonomian dalam negara yang bersangkutan.

\section{Founding Fathers Negara Indonesia}

Dalam sub judul ini jika ditinjau dari perannya dalam masalah kenegaraan memang seharusnya nama Soekarno (populer juga disebut Bung Karno), namun karena pokok bahasan dalam penelitian ini adalah menitik beratkan pada ekonomi maka nama Mohammad Hatta (yang juga populer dengan sebutan Bung Hatta) adalah pakar ekonomi Indonesia pertama yang peranya sangat menonjol dalam hubunganya dengan masalah kenegaraan.

\section{a. Mohammad Hatta (1902-1982 M)}

Menurut Bung Hatta ekonomi terpimpin adalah lawan dari ekonomi liberal yang telah melahirkan sistem kapitalisme. Semboyannya ialah 'laissez faire' ('biarkan saja'), artinya biarkan pasar bertindak bebas dalam membangun kehidupan ekonomi dan perdagangan. Ekonomi liberal menghendaki pemerintah tidak campur tangan dalam perekonomian rakyat dengan membuat peraturan-peraturan ketat (regulasi) yang membatasi gerak bebas pasar. Ekonomi terpimpin adalah sebaliknya. Pemerintah harus aktif bertindak dan memberlakukan peraturan terhadap perkembangan ekonomi dalam masyarakat agar rakyat tidak dieksploitasi, harga tidak dipermainkan dan dengan demikian tercapai keadilan sosial. Alasan mengapa ekonomi terpimpin dipandang sesuai dengan cita-cita nasionalisme Indonesia ialah: Karena membiarkan perekonomian berjalan menmurut permainan bebas dari tenagatenaga masyarakat berarti membiarkan yang lemah menjadi makanan yang kuat. Ekonomi liberal bercita-cita memberikan kemakmuran dan kemerdekaan bagi semua orang, tetapi hasilnya menimbulkan pertentangan dan kesengsaraan. Yang kaya bertambah kaya, yang miskin bertambah melarat. Sebab

${ }^{30}$ Gaston Bouthoul, Teori-teori Filsafat Sosial Ibn Khaldun, terj. Yudian W. Asmin (Yogyakarta: Titian Ilahi Press, 1998), h. 52. 
kebebasan atau liberalisme yang disandang oleh sistem itu dalam kenyataan hanya dimiliki segolongan kecil orang (yaitu pemilik modal atau kapital) dan kepada mereka yang segelintir itu sajalah keuntungan dan kemakmuran berpihak, bukan kepada rakyat banyak. Sedangkan untuk Indonesia dengan Pancasila sebagai asasnya menghendaki "Keadilan Sosial bagi Seluruh Rakyat Indonesia" yang kontra indikasi dengan Liberalisme itu.

Sebuah kutipan dari pakar ekonomi yang juga proklamator Indonesia Bung Hatta yang berpendirian bahwa, Ekonomi terpimpin secara istilah yang disebutkan Bung Hatta yaitu merupakan konsekuensi dan nasionalisme yang timbul sebagai bentuk dari perlawanan menentang kolonialisme dan imperialisme. Prinsip ekonomi terpimpin sejalan dengan sila ke-5 Pancasila yaitu Keadilan Sosial bagi Seluruh Rakyat Indonesia. Dikarenakan adanya pemerataan pembagian kesejahteraan di semua lapisan masyarakat dan mereka dapat merasakannya. Ekonomi terpimpin serupa dengan ekonomi sosialis. Menurut Bung Hatta ekonomi terpimpin merupakan rival dari sistem ekonomi liberal. Dimana segala sesuatunya ditentukan oleh pihak pasar, sedangkan pemerintah tidak boleh campur tangan dalam hal tersebut. Atau juga ikut andil dalam mengatur keadaan pasar sehingga peraturan tersebut tidak memberikan gerak bebas bagi pasar. ${ }^{31}$ Dalam kesempatan lain Bung Hatta pernah menyatakan bahwa campur tangan pemerintah itu memang harus ada namun sebatas upaya menegakkan keadilan, dalam rangka membendung tindakan yang dapat merugikan orang banyak, seperti halnya monopoli perdagangan atau produksi dan sebagainya. Hal ini mengingatkan kita kepada sila kelima Pancasila, karena Pancasila adalah soko guru bagi kehidupan berbangsa dan bernegara di Indonesia.

Dalam pembangunan sosial budaya perlu ditumbuhkembangkan kembali budaya malu, dan budaya keteladanan. Di bidang ekonomi, Pancasila juga menjadi landasan nilai dalam pelaksanaan perkembangan ekonomi. Pembangunan Ekonomi yang berdasarkan atas nilai-nilai Pancasila selalu mendasar pada nilai kemanusiaan artinya pembangunan ekonomi untuk kesejahteraan umat manusia, pembangunan ekonomi semata melainkan demi kemanusiaan dan kesejahteraan seluruh bangsa. ${ }^{32}$ Nyata benar di sini bahwa Pancasila adalah

31Ridho Yahya, "Sejarah Singkat Bung Hatta sebagai Pemrakarsa Ekonomi Terpimpin", 2009, dalam http://ridhoyahya89.blogspotcom, 2-3, diakses 07-12-2010.

32Instifun Siddiq, tth., "Pancasila sebagai Ideologi Negara dan Dasar Negara", http:// istifunnyassyidiq.wordpress.com; h. 7, diakses 23-02-2015. 
sumber dari segala sumber hukum bahkan dalam tata ekonomi pun tidak ada landasan lain bagi bangsa Indonesia kecuali Pancasila yang medudukkan masalah Ketuhanan sebagai yang utama dan pertama, maka sudah tepatlah kau di Indonesia saat ini marak sekali eksisensi Bank Syari’ah.

\section{b. Soekarno (1901-1970)}

Bung Karno mengatakan bahwa kemerdekaan politik hanya sebagai jembatan emas untuk menuju tujuan terbentuknya masyarakat yang adil dan makmur berdasarkan Pancasila. ${ }^{33}$ Bung Karno pernah menyatakan dalam satu amanatnya, Kalau kita mencari demokrasi hendaknya bukan demokrasi barat, tetapi permusyawaratan yang memberi hidup, yakni politik economische democratie yang mampu mendatangkan kesejahteraan sosial! Rakyat Indonesia sudah lama bicara tentang hal ini. Apakah yang dimaksud dengan Ratu Adil? Yang dimaksud dengan faham Ratu Adil ialah social rechtvaardigheid. Rakyat ingin sejahtera. Rakyat yang tadinya merasa dirinya kurang makan kurang pakaian, menciptakan dunia baru yang di dalamnya ada keadilan, di bawah pimpinan Ratu Adil. 34

Demokrasi ekonomi, jika diurut dari arti kata "kratos" yang berarti rakyat maka patut diartikan ekonomi yang pro rakyat banyak sebagaimana pengertian istilah sila kelima Pancasila yakni Keadilan Sosial bagi Seluruh Rakyat Indonesia. ${ }^{35}$

\section{Pakar Ekonomi}

Sejalan dengan pandangan Bung Hatta tentang Liberalisme seorang pakar ekonomi Indonesia juga berpendirian bahwa, karena pasar merupakan salah satu relasi yang diciptakan untuk membantu pengadaan kebutuhan barang/jasa bagi hidup bersama, dinamika perubahan sosial tidak dapat diserahkan kepada kinerja pasar tanpa kerangka tata-sosial. Itulah mengapa Ordo-Liberal menolak determinisme perubahan menurut dalil ekonomi ala laissez-faire dan juga Marxisme ortodoks. Bagi Ordo-Liberal, fokus perdebatan tentang perubahan

\footnotetext{
12-2010;

${ }^{33}$ Kartaprawira, M.D., t.th., Kritik-Ajaran-Bung-Karno, http://www.syarikat.org., h. 27, diakses, 01-

${ }^{34}$ Soekarno, http://id.wikiquote.org/wiki/Soekarno, diakses 20-01-2011; h. 10-11.

${ }^{35}$ Cindy Adams, Sukarno an Auto Biography as Told to Cndy Adams (New York: The Bobbs Merril Company Inc., 1965).
} 
bukan terletak dalam pertanyaan sejauh mana bidang/relasi sosial-politikkultural digerakkan oleh ekonomi pasar (seperti dalam neo-liberalisme sekarang), tetapi sejauh mana kinerja pasar membantu terjadinya kontrak sosial'. Dalam arti ini, premis Ordo-Liberal tentang manusia bukanlah homo oeconomicus, tetapi homo socialis. ${ }^{36}$ Sedangkan Indonesia dengan Sila Kelima Pancasila-nya yakni Keadilan Sosial Bagi Seluruh Rakyat Indonesia, jelas tidak sejalan, demikian pun pakar ekonomi Indonesia lainnya berpendapat, buruknya kondisi sosial, ekonomi, dan keagamaan tersebut terutama disebabkan oleh keadaan politik yang kacau. ${ }^{37} \mathrm{Di}$ atas telah disinggung sepintas tentang instabilitas dalam suatu negara yang akan berakibat sangat buruk bagi rakyat maupun bagi pemerintahnya. Akan tetapi jika stabilitas dalam suatu negara dapat terjaga tentunya kontrak sosial juga akan tercipta.

Dengan memperhatikan perjalanan sejarah Indonesia Soerjadi berpendapat bahwa, ekonomi terpimpin adalah kebalikan dari perekonomian liberal. Menurutnya, ekonomi liberal adalah kehidupan ekonomi dimana mekanisme harga dijadikan pedoman dalam proses produksi dan pemerintah tidak turut mempengaruhi perkembangan harga tersebut, dan jika pemerintah turut campur mempengaruhi mekanisme harga, maka sistem ekonomi tersebut disebut ekonomi terpimpin. Soerjadi menambahkan bahwa ekonomi terpimpin adalah ekonomi berencana, ekonomi yang digerakkan oleh suatu rencana yang dibikin dan dilaksanakan secara sadar oleh pemerintah untuk menghadapi permasalahan ekonomi ${ }^{38}$ Ekonomi terpimpin pada hakikatnya adalah suatu model tata ekonomi yang didesain untuk menjaga hal-hal yang kontradiksi dengan asas negara Pancasila khususnya yang terkait dengan sifat adil dan merata. Sebagai lawan dari sifat-sifat monopoli ataupun yang sebangsanya, yang tidak relevan dengan sifat keadilan dan pemerataan atau yang tidak demokratis, sebagaimana yang dicita-citakan oleh Bung Karno di atas.

Economic democracy is typically used to denote a variety of forms of employee participation in the ownership of enterprises and in the distribution of economic rewards; Industrial democracy refers to the notion 06-2011.

36Herry-Priyono, B., "Neoliberalisme dan Kebebasan”., http://www.unisosdem.org; diakses 14-

${ }^{37}$ Anonim, 2014, Kekhalifahan_Umayyah, http://id.wikipedia.org/wiki, diakses 8 Juli 2014.

${ }^{38}$ Syarif Hidayatullah, 2010, http://www.kompasiana.com/saripoenya, diakses 05-02-2011. 
of worker participation in decision-making and employee involvement in the processes of control within the firm.

Meskipun pengertian economic democracy jelas lebih luas dari industrial democracy namun keduanya bisa diterapkan sebagai asas atau "style" manajemen satu perusahaan yang jika dilaksanakan dengan disiplin tinggi akan menghasilkan kepuasan semua pihak (stakeholders) yang terlibat dalam perusahaan. Itulah demokrasi industrial yang tidak lagi menganggap modal dan pemilik modal sebagai yang paling penting dalam perusahaan, tetapi dianggap sederajat kedudukannya dengan buruh/ tenaga kerja, yang berarti memberikan koreksi atau reformasi pada kekurangan sistem kapitalisme lebih-lebih yang bersifat neoliberal. ${ }^{39}$ Kesetaraan di sini sangat bersifat ke Indonesiaan yang juga Islami, maka wajar saja kalau saat ini berkembang pesat lembaga-lembaga keuangan yang bersifat Syari'ah termasuk Baitul Mal wat Tamwil (BMT) atau yang juga biasa disebut dengan Istilah Koperasi Jasa Keuangan Syari'ah (KJKS).

Faktor inilah yang akhir-akhir ini menyebabkan makin berkembangnya pemikiran dan praktek "bank-bank syariah" yang berarti secara serius memasukkan ajaran-ajaran agama Islam dalam praktek-praktek perbankan kapitalis yang telah mengakibatkan krisis moneter dan krisis perbankan, yang sampai 5 tahun tetap belum teratasi. Bahkan upaya pemerintah menyelamatkan perbankan nasional dengan mengeluarkan dana-dana amat besar (obligasi rekap perbankan melebihi 50\% PDB), tokh tidak menunjukkan tanda-tanda akan berhasil, selama ajaran-ajaran agama tidak dipergunakan dalam upaya penyelamatan tersebut. Di kalangan agama-agama lain (Katolik dan Hindu) juga makin intensif dibahas peranan nilai-nilai agama untuk membendung ajaranajaran ekonomi neoliberal yang meluas melalui globalisasi yang makin merajalela, yang dapat dilakukan oleh gereja adalah mendidik umat bersama masyarakat agar semakin bersedia melepaskan diri dari keserakahan modernisme, konsumerisme, dan kolonialisme kultural ke arah pemahaman tanggung jawab bersama. ${ }^{40}$ Bank Syari'ah di Indonesia saat ini sangatlah marak sebab selain memang padanya berlaku sistem keuangan yang Islami juga sesuai dengan kepribadian Indonesia Pancasila. Sehingga beberapa Pemerintah Daerah

${ }^{39}$ Mubyarto, 2003, "Demokrasi Ekonomi dan Demokrasi Industrial", http://www. ekonomirakyat.org, diakses 06-10-2010.

${ }^{40} \mathrm{Ibid}$. 
secara kelembagaan turut mendirikan Bank Syari'ah sebagai salahsatu Badan Usaha Milik(BUMD).

\section{Antara Founding Fathers Negara Indonesia dan Filosof Muslim}

Berapa sumber di atas memberi petunjuk kepada penulis yang terkait dengan permasalahan masyarakat adil makmur versi founding fathers negara Indonesia dalam perspektif filosof Muslim terkait dengan masalah masyarakat adil makmur. Pada bagian pendahuluan telah dikutip pandangan Ibnu Taimiyah yang menyatakan bahwa, sesungguhnya mengatur urusan manusia merupakan kewajiban agama yang paling besar/bahkan agama tidak akan tegak tanpa hal itu. Di sini dapat dipahami bagi Muslim Indonesia dalam hubunganya dengan Pancasila yakni sila pertama. Jika negara mendudukkan masalah Ketuhanan sebagai yang pertama dan utama tentu dalam rangka mewujudkan masyarakat adil makmur tidak dapat dilepaskan dari nilai-nilai Ketuhanan Yang Maha Esa.

Demikianpun Ibnu Abi Rabi' yang menyatakan, Tuhan juga telah mengangkat penguasa-penguasa yang harus bertugas untuk menjaga berlakunya peraturan-peraturan rakyat dari Tuhan dan mengendalikan masyarakat berdasarkan hukum Tuhan. Kebalikan dari pandangan ini sebagaimana celaan dari Bung Hatta yang berpendapat, ekonomi terpimpin adalah lawan dari ekonomi liberal yang telah melahirkan sistem kapitalisme. Semboyannya ialah 'Iaissez faire' ('biarkan saja'), artinya biarkan pasar bertindak bebas dalam membangun kehidupan ekonomi dan perdagangan. Ekonomi liberal menghendaki pemerintah tidak campur tangan dalam perekonomian rakyat dengan membuat peraturan-peraturan ketat (regulasi) yang membatasi gerak bebas pasar. Landasan dari pandangan Bung Hatta di sini tiada lain kecuali sila Kelima Pancasila yakni Keadilan Sosial Bagi Seluruh Rakyat Indonesia.

Lebih tegas pada Ibnu Khaldun, Keadilan itu ada karena kejujuran aparatur negara, dan kejujuran aparatur negara itu karena adanya kejujuran para wāzir (menteri), yang berada dibawah pengawasan seorang Raja serta tergantung pula kepada kemampuan sang raja dalam bersikap dan bertindak. Sejalan dengan Ibnu Khaldun proklamator Republik Indonesia menyatakan, Apakah yang dimaksud dengan Ratu Adil? Yang dimaksud dengan faham Ratu Adil ialah social rechtvaardigheid. Rakyat ingin sejahtera. Rakyat yang tadinya merasa dirinya kurang makan kurang pakaian, menciptakan dunia baru yang di 
dalamnya ada keadilan. Memang tidak bisa dipungkiri bahwa eksistesi pemerintah yang selalu siap menegakkan keadilan, sebab bagaimanapun hebatnya tata hukum jika ekskutif dan legislatifnya tidak mampu menegakkan keadilan niscahya keadilan hanya ada dalam impian semata. Cita-cita Bung Karno yang mulia itu menuntut akan adanya integritas para aparatur negara dalam bidang tugasnya.

Patut dijadikan catatan bagi segenap warga negara pendapat pakar ekonomi Soerjadi menyatakan bahwa ekonomi terpimpin adalah ekonomi berencana, ekonomi yang digerakkan oleh suatu rencana yang dibuat dan dilaksanakan oleh pemerintah untuk menghadapi masalah ekonomi. Istilah berencana di sini patut disamakan dengan apa yang pernah dinyatakan Bung Hatta tentang campur tangan pemerintah dalam hal penataan agar tidak terjadi kesewenang-wenang dari para pelaku ekonomi. Lebh lanjut al-Farabi menyatakan bahwa, keadilan itu sangat bersangkut paut dengan distribusi dan juga pemeliharaan harta benda yang berharga, semua ini dinyatakan secara tegas berupa keamanan, pemeliharaan harta benda di sini dapat diartikan sebagai kata lain dari ekonomi terpimpin dalam artian terpimpin dengan aturan-aturan dari pemerintah demi tegaknya keadilan di bidang ekonomi.

\begin{tabular}{|c|l|l|}
\hline No. & \multicolumn{1}{|c|}{$\begin{array}{c}\text { Founding Fathers } \\
\text { Negara Indonesia }\end{array}$} & \multicolumn{1}{c|}{ Filosof Muslim } \\
\hline 1. & $\begin{array}{l}\text { Menurut Bung Karno Faham Ratu } \\
\text { Adil ialah social rechtvaardigheid, } \\
\text { dengan landasan Pancasila. } \\
\text { Sebagian Pakar Ekonomi Indonesia } \\
\text { berpendapat bahwa, bangsa } \\
\text { Indonesia harus bersedia } \\
\text { melepaskan diri dari keserakahan } \\
\text { modernisme, konsumerisme, dan } \\
\text { kolonialisme. }\end{array}$ & $\begin{array}{l}\text { Masyarakat Adil Makmur tidak dapat } \\
\text { dilepaskan dari nilai-nilai Ketuhanan } \\
\text { Yang Maha Esa. Orang yang harus } \\
\text { mencegah orang lain dari kejahatan } \\
\text { itu adalah orang yang mampu } \\
\text { menjadi contoh dari aparatur negara } \\
\text { maupun rakyatnya. }\end{array}$ \\
\hline 2. & $\begin{array}{l}\text { Menurut Bung Hatta, ekonomi } \\
\text { terpimpin adalah lawan dari } \\
\text { ekonomi liberal yang telah } \\
\text { melahirkan sistem kapitalisme. }\end{array}$ & $\begin{array}{l}\text { Menurut Khaldun, Agama } \\
\text { menetralisir persaingan tidak sehat } \\
\text { antar sesama guna mewujudkan } \\
\text { solidaritas, dan tujuan yang sama. }\end{array}$ \\
\hline
\end{tabular}




\section{Kesimpulan}

Setelah penulis menelusuri liku-liku pandangan para filosof Muslim, founding fathers negara Indonesia serta para pakar di bidang politik dan ekonomi sepanjang masalah yang berkaitan dengan negara adil makmur maka diperoleh suatu kesimpulan sebagai berikut:

Negara adil makmur adalah negara yang secara nyata dapat mewujudkan demokrasi dalam segala sisi dan segi kehidupan berbangsa dan bernegara. Wajib diberlakukan hukum dalam suatu negara yang sifat adilnya pro kepada rakyat banyak, namun untuk kepentingan itu, Keadilan itu ada karena kejujuran aparatur negara. Konsep ekonomi terpimpin secara essensial memang baik namun, diperlukan adanya niat baik dan sikap yang konsisten dari penyelenggara negara yang selalu siap dengan integritasnya untuk mewujudkan negara yang adil dan makmur.]

\section{DAFTAR PUSTAKA}

Adams, Cindy, Sukarno an Auto Biography as Told to Cndy Adams, New York: The Bobbs Merril Company Inc., 1965.

Ahmad, Zainal Abidin, Konsep Politik dan Ideologi Islam, Jakarta: Bulan Bintang, 1977.

Alam, Wawan Tunggul (ed), Bung Karno Menggali Pancasila, Kumpulan Pidato, Jakarta: Gramedia Pustaka Utama, 2001.

Anonim, "Kekhalifahan_Umayyah", http://id.wikipedia.org/wiki, diakses 8 Juli 2014.

Asshidiqie, Jimly, Format Kelembagaan Negara dan Pergeseran Kekuasaan Dalam UUD. 1945, Yogyakarta: UII Pres, 2005.

Bouthoul, Gaston, Teori-teori Filsafat Sosial Ibn Khaldun, terj. Yudian W. Asmin, Yogyakarta: Titian Ilahi Press, 1998.

Fakhry, Majid, Sejarah Filsafat Islam, terj. Mulyadi, Jakarta: Temprin, 1987.

Ghazali, Adeng Muchtar, Civic Education; Pendidikan Kewarga-negaraan Perspektif Islam, Bandung: Benang Merah Press, 2004. 
Herry-Priyono, "Neoliberalisme dan Kebebasan", http://www.unisosdem. org, diakses 14-06-2011.

Ibn Khaldun, Muqaddimah, terj. Ahmadi Thoha, Jakarta: Pustaka Firdaus, 1986.

Instifun Siddiq, "Pancasila sebagai Ideologi Negara dan Dasar Negara", http://istifunnyassyidiq.wordpress.com, diakses 23-02-2015.

Kartaprawira, M.D., "Kritik-Ajaran-Bung-Karno", http://www.syarikat.org., diakses, 01-12-2010.

Khan, Qomarudin, Pemikiran Politik Ibnu Taimiyah, terj. Anas Mahyuddin, Bandung: Salman ITB, 1983.

Lauer, Robert, H, Perspektif Tentang Perubahan Sosial, terj. Alimandan, Jakarta: Bina Aksara, 1989.

Maarif, Ahmad Syafii, Islam dan Masalah Kenegaraan, Jakarta: LP3ES, 1990.

Mallarangeng, Andi, dkk, Otonomi Daerah, Demokrasi dan Civil Society, Jakarta: Media Grafika, 2000.

Mubyarto, 2003, "Demokrasi Ekonomi dan Demokrasi Industrial", http://www. ekonomirakyatorg diakses 06-10-2010.

Notonagoro, Pancasila Secara Ilmiah Populer, Jakarta: Bumi Aksara, 1997.

Poerwantana, A. Ahmadi dan M. A. Rosali, Seluk beluk Filsafat Islam, Bandung: Rosda Karya, 1988.

Poerwantana, dkk, Seluk-beluk Filsafat Islam, Bandung: CV Rosda Bandung, 1988,

Pranarka, A.M.W., Sejarah Pemikiran tentang Pancasila, Jakarta: CSIS, 1985.

Siddiq, Instifun Instifun, tth., "Pancasila Sebagai Ideologi Negara dan Dasar Negara," http://istifunnyassyidiq.wordpress.com, diakses 23-02-2015.

Siswanto, Joko, Filsafat Politik Pancasila, Refleksi atas Teks Perumusan Pancasila, Yogyakarta: Kkepel Press, 2007.

Syadzali, Munawwir, Islam dan Demokrasi, Jakarta: UI. Press, 1996.

Syarif Hidayatullah, http://www.kompasiana.com/saripoenya, diakses 05-022011. 
Widjanarno, Ade A., Transisi Menuju Demokrasi, Tinjauan Berbagai Perspektif, Jakarta: LP3ES, 1983.

Yahya, Ridho, "Sejarah Singkat Bung Hatta Sebagai Pemrakarsa Ekonomi Terpimpin", http://ridhoyahya89.blogspot.com, diakses 07-12-2010.

Yatim, Badri, Soekarno Islam dan Nasionalisme, Jakarta: Logos, 1999.

Zaidan, Abdul Karim, Masalah Kenegaraan dalam Islam, terj. Abd.Azis, Jakarta: Al Amin, 1984.

Zullifan, 2008, http://muhammad-zulifan.multiply.com. diakses 07-09-2010. 
